\title{
Anandamide amidohydrolase reacting with 2-arachidonoylglycerol, another cannabinoid receptor ligand
}

\author{
Sravan Kumar Goparaju, Natsuo Ueda, Hiroko Yamaguchi, Shozo Yamamoto* \\ Department of Biochemistry, Tokushima University, School of Medicine, Kuramoto-cho, Tokushima 770, Japan
}

Received 11 December 1997

\begin{abstract}
Two endogenous ligands for cannabinoid receptors, anandamide (arachidonylethanolamide) and 2-arachidonoylglycerol, lose their biological activities by enzymatic hydrolysis. A cDNA for a rat liver enzyme hydrolyzing anandamide as well as oleamide was overexpressed in COS-7 cells. When the particulate fraction was allowed to react with 2-arachidonoylglycerol, arachidonic acid was produced. In contrast, this hydrolytic reaction did not occur with the control cells. The hydrolysis of 2arachidonoylglycerol proceeded about 4-fold faster than the anandamide hydrolysis with a $K_{\mathrm{m}}$ value as low as $6 \mu \mathrm{M}$ and an optimal pH of 10 . Phenylmethylsulfonyl fluoride and methyl arachidonyl fluorophosphonate inhibited the hydrolysis of both anandamide and 2-arachidonoylglycerol in parallel. Furthermore, the hydrolysis of $\left[{ }^{14} \mathrm{C}\right] 2$-arachidonoylglycerol was inhibited by anandamide dose-dependently. These results suggest that anandamide and 2-arachidonoylglycerol can be inactivated by the same enzyme.
\end{abstract}

(c) 1998 Federation of European Biochemical Societies.

Key words: Cannabinoid; Anandamide;

2-Arachidonoylglycerol; Amidohydrolase; COS-7 cell

\section{Introduction}

Cannabinoids exert their various biological effects through membrane-bound specific receptors: the central type (CB1) and the peripheral type (CB2) [1-3]. As an endogenous ligand for these receptors, anandamide (arachidonylethanolamide) was isolated from porcine brain [4]. Later, 2-arachidonoylglycerol (2-AG) was isolated from canine gut [5] and rat brain [6] as another endogenous ligand.

Anandamide loses its biological activity when it is hydrolyzed to arachidonic acid and ethanolamine [7]. The enzyme responsible for the hydrolysis is found in various mammalian organs and cell lines, and is referred to as anandamide amidase or amidohydrolase [7-15]. Recently a cDNA for fatty acid amide hydrolase was cloned from a cDNA library of rat liver by Cravatt et al. [16]. Although this enzyme was originally studied as an amidohydrolase of oleamide as a sleep inducer, a recombinant enzyme overexpressed in COS-7 cells was more active with anandamide than oleamide [16], suggesting that the enzyme was identical to the previously known anandamide amidohydrolase. We also overexpressed the rat fatty acid amide hydrolase in COS-7 cells, and confirmed the higher reactivity of the recombinant enzyme with anandamide than with oleamide [17]. Therefore, in this paper we will refer to the recombinant preparation of 'fatty acid amide hydrolase' as 'anandamide amidohydrolase'. Furthermore, we found that the enzyme could hydrolyze methyl arachidonate, indicating

\footnotetext{
*Corresponding author. Fax: (81) (886) 33-6409.
}

that the enzyme possessed not only an amidohydrolase activity but also a carboxylesterase activity for long-chain fatty acyl esters [17]. On the basis of this finding, we investigated whether or not the recombinant enzyme hydrolyzed the ester bond of 2-AG, the other cannabimimetic compound, in addition to anandamide.

\section{Materials and methods}

\subsection{Materials}

2-AG was kindly provided by Dr. Hiroyuki Iwamura of Japan Tobacco Inc., Central Pharmaceutical Research Institute (Osaka, Japan), and was also purchased from Deva Biotech (Hatboro, PA). [1$\left.{ }^{14} \mathrm{C}\right]$ Arachidonic acid and 1-stearoyl-2-[1-14 C]arachidonyl-sn-glycerol were purchased from Amersham International (Amersham, UK), arachidonic acid, 1(3)-arachidonoylglycerol (1-AG), oleic acid and 1,3-dioleoylglycerol from Nu-Chek-Prep (Elysian, MN), anandamide and methyl arachidonyl fluorophosphonate (MAFP) from Cayman Chemical Company (Ann Arbor, MI), 1,2-dioleoylglycerol from Doosan Serdary Research Laboratories (Englewood Cliffs, NJ), 1-stearoyl2-arachidonyl-sn-glycerol from Biomol (Plymouth Meeting, PA), and 1-monooleoylglycerol, phenylmethylsulfonyl fluoride (PMSF) and Rhizopus arrhizus lipase from Sigma (St. Louis, MO). [arachidonyl$\left.1-{ }^{14} \mathrm{C}\right]$ Anandamide was chemically prepared from $\left[1-{ }^{14} \mathrm{C}\right]$ arachidonic acid and ethanolamine as described previously [18]. 2-[1- $\left.{ }^{14} \mathrm{C}\right]$ Arachidonoyl-sn-glycerol was prepared by the digestion of 1-stearoyl-2-[1${ }^{14}$ C]arachidonyl-sn-glycerol with Rhizopus arrhizus lipase [19], and was purified by silica gel thin-layer chromatography (TLC) with a solvent mixture of diethyl ether/petroleum ether/acetic acid $(85: 15: 0.1, \mathrm{v} / \mathrm{v})$. pcDNA3.1(+) vector was obtained from Invitrogen (Carlsbad, CA) and Lipofectamine from Gibco-BRL (Gaithersburg, MD).

\subsection{Enzyme preparation}

COS-7 cells were transfected with pcDNA3.1(+) vector harboring cDNA for rat anandamide amidohydrolase with the aid of Lipofectamine as we described previously [17]. The transfected cells were harvested, and sonicated three times each for $3 \mathrm{~s}$ in $20 \mathrm{mM}$ Tris- $\mathrm{HCl}$ buffer ( $\mathrm{pH} 8.0$ ). The lysate was ultracentrifuged at $267000 \times g$ for 20 min, and the resultant pellet (particulate fraction) was suspended in 20 $\mathrm{mM}$ Tris- $\mathrm{HCl}$ buffer ( $\mathrm{pH} 8.0$ ). COS-7 cells transfected with the insertfree pcDNA 3.1(+) were used as a control. Protein concentration was determined by the method of Bradford [20] with bovine serum albumin as standard.

\subsection{Enzyme assay}

The particulate fraction of the transfected COS-7 cells was incubated with $2-\mathrm{AG}$ or anandamide dissolved in $10 \mu \mathrm{l}$ of dimethyl sulfoxide at $50 \mu \mathrm{M}$ final concentration in the presence of $200 \mu 1$ of $50 \mathrm{mM}$ Tris- $\mathrm{HCl}\left(\mathrm{pH} \mathrm{9.0)}\right.$ at $37^{\circ} \mathrm{C}$ for $1 \mathrm{~min}$. The reaction was terminated by the addition of $0.5 \mathrm{ml}$ of cold diethyl ether and $20 \mu \mathrm{l}$ of $1 \mathrm{~N} \mathrm{HCl}$. The ethereal extract $(0.2 \mathrm{ml})$ was dried, and a one-fourth sample was then subjected to reverse-phase high-performance liquid chromatography (HPLC) using a TSK gel column (type ODS-120T, $5 \mu \mathrm{m}, 4.6 \times 250$ $\mathrm{mm}$, Tosoh) equipped with a Waters 600E System Controller. The solvent system was a mixture of methanol/water/acetic acid $(90: 10: 0.01, \mathrm{v} / \mathrm{v})$ at a flow rate of $1.0 \mathrm{ml} / \mathrm{min}$. Absorption at 205 nm was monitored with a Waters Photodiode Array Detector Model 490. On the basis of peak areas of the substrate (2-AG or anandamide) and the product (free arachidonic acid), the conversion rate was estimated. When standard mixtures of $2-\mathrm{AG}$ and arachidonic acid 


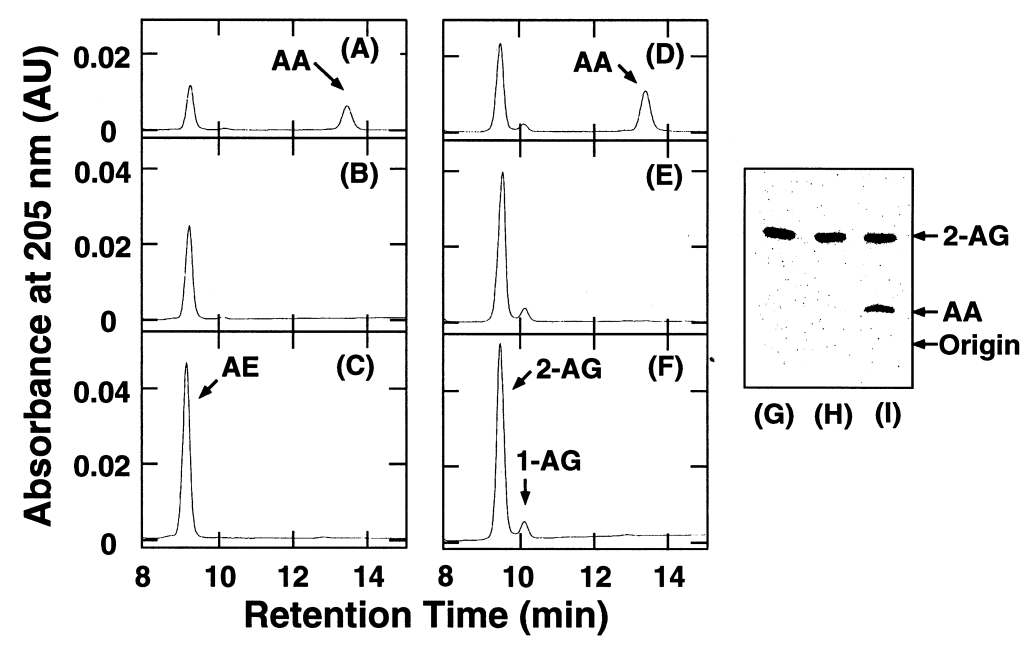

Fig. 1. Hydrolysis of anandamide and 2-AG by COS-7 cells overexpressing rat anandamide amidohydrolase. The particulate fractions (14.0 $\mu \mathrm{g}$ protein) of the transfected COS-7 cells (A) and the control COS-7 cells (B) and the protein-free buffer (C) were incubated with $50 \mu \mathrm{M}$ anandamide. The particulate fractions (3.5 $\mu \mathrm{g}$ protein for HPLC analysis and $2.0 \mu \mathrm{g}$ protein for TLC analysis) of the transfected COS-7 cells (D,I) and the control COS-7 cells $(\mathrm{E}, \mathrm{H})$ and the protein-free buffer $(\mathrm{F}, \mathrm{G})$ were also incubated with $50 \mu \mathrm{M}$ 2-AG. The formation of arachidonic acid was analyzed by reverse-phase HPLC (A-F) or TLC (G-I) as described in Section 2. Arrows indicate the positions of standard compounds: AA, arachidonic acid; AE, anandamide; 1-AG, 1(3)-arachidonoylglycerol; 2-AG, 2-arachidonoylglycerol.

with different molar ratios were added to $50 \mathrm{mM}$ Tris- $\mathrm{HCl}$ buffer $(\mathrm{pH}$ 9.0), extracted with diethyl ether, and analyzed by HPLC, the ratios of peak areas for these two compounds were exactly in agreement with their original ratios. Since transesterification of $2-\mathrm{AG}$ to $1-\mathrm{AG}$ is accelerated by acid or base or heat [21], we purified 2-AG before use by straight-phase HPLC using a Waters $\mu$ Porasil column $(3.9 \times 300$ $\mathrm{mm})$. The solvent system was a mixture of hexane/2-propanol/acetic acid $(95: 5: 0.1, \mathrm{v} / \mathrm{v})$ at a flow rate of $2.0 \mathrm{ml} / \mathrm{min}$. More than $93 \%$ purity was achieved by this method. The 1-AG preparation (Nu-Chek-Prep) contained around 6\% 2-AG as analyzed by our reverse-phase HPLC system, and was used without further purification.

The enzyme assay was also carried out using TLC. The enzyme was incubated with $50 \mu \mathrm{M} 2-\left[1-{ }^{14} \mathrm{C}\right]$ arachidonoyl-sn-glycerol $(5000 \mathrm{cpm} / 5$ $\mathrm{nmol} / 5 \mu \mathrm{l}$ of dimethyl sulfoxide) or $50 \mu \mathrm{M}$ [arachidonyl-1${ }^{14} \mathrm{C}$ ]anandamide $(10000 \mathrm{cpm} / 5 \mathrm{nmol} / 5 \mu \mathrm{l}$ of dimethyl sulfoxide $)$ in $100 \mu \mathrm{l}$ of $50 \mathrm{mM}$ Tris- $\mathrm{HCl}\left(\mathrm{pH} \mathrm{9.0)}\right.$ at $37^{\circ} \mathrm{C}$ for $1 \mathrm{~min}$. The reaction was terminated by the addition of $0.3 \mathrm{ml}$ of cold diethyl ether and 10 $\mu \mathrm{l}$ of $1 \mathrm{~N} \mathrm{HCl}$. The ethereal extract was spotted on a Merck silica gel $60 \mathrm{~F} 254$ glass plate $(10 \mathrm{~cm}$ height), which was developed in a mixture of chloroform $/$ methanol $/ 25 \%$ ammonium hydroxide $(80: 20: 2$, v/v) for $20 \mathrm{~min}$ at room temperature. Radioactivity on the plate was scanned with a Fujix BAS2000 bioimaging analyzer.

\section{Results}

COS-7 cells were transfected with an eukaryotic expression vector harboring cDNA for rat anandamide amidohydrolase. The particulate fraction of the transfected cells was incubated with anandamide, and the ethereal extract was analyzed by reverse-phase HPLC. When absorption at $205 \mathrm{~nm}$ was monitored for double bonds of the arachidonate moiety, a peak of free arachidonic acid was observed in addition to the remaining anandamide (Fig. 1A). The particulate fraction of the control cells did not produce arachidonic acid (Fig. 1B). This result confirmed the activity of the recombinant enzyme which was previously shown by the TLC assay using radioactive anandamide as a substrate [16,17]. Furthermore, when the enzyme was allowed to react with 2-AG, arachidonic acid was produced (Fig. 1D). However, arachidonic acid was not detected with the control cells (Fig. 1E). Since 2-AG was spontaneously transformed to $1-\mathrm{AG}$ in $50 \mathrm{mM}$ Tris- $\mathrm{HCl}$ at pH 9.0 which we used for the enzyme assay, we performed the enzyme reaction only for $1 \mathrm{~min}$. After the 1-min incubation of 2-AG in the buffer, the ratio of 2-AG to 1-AG was 93:7 (Fig. $1 \mathrm{~F})$. We also incubated the enzyme preparation with 2-[1${ }^{14}$ C]arachidonoyl-sn-glycerol, and the radioactive product was separated by TLC. The formation of $\left[{ }^{14} \mathrm{C}\right]$ arachidonic acid was observed with the transfected cells (Fig. 1I), but not with the control cells (Fig. 1H). These results indicate that the recombinant preparation of anandamide amidohydrolase catalyzed the hydrolysis of 2-AG.

The rate of 2-AG hydrolysis increased depending on the enzyme amounts (Fig. 2A). As examined with $2.5 \mu \mathrm{g}$ protein, the specific activity was $1.1 \mu \mathrm{mol} / \mathrm{min} / \mathrm{mg}$ protein at $37^{\circ} \mathrm{C}$, which was about 4-fold higher than that of the anandamide hydrolysis by the same enzyme. The reaction rate increased depending on the concentrations of $2-\mathrm{AG}$, and the $K_{\mathrm{m}}$ value
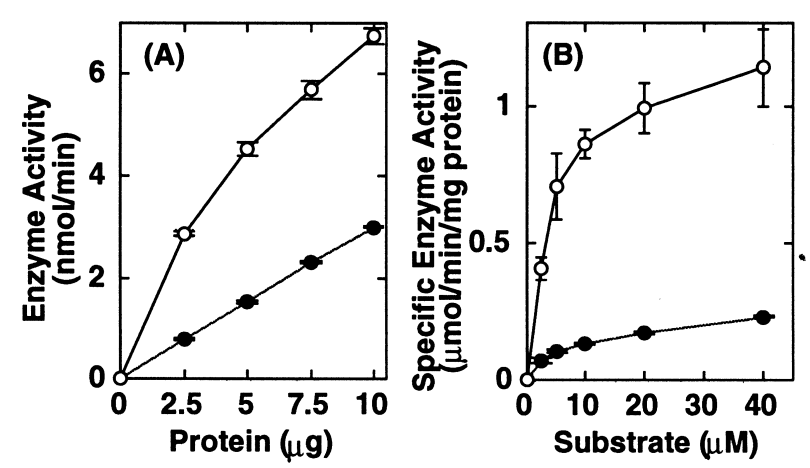

Fig. 2. Reactivity of anandamide amidohydrolase with anandamide and 2-AG depending on protein amounts and substrate concentrations. A: Different amounts of the particulate fraction of the transfected COS-7 cells were allowed to react with $50 \mu \mathrm{M}$ anandamide (closed circles) or $50 \mu \mathrm{M} 2-\mathrm{AG}$ (open circles). B: The particulate fraction of the transfected COS-7 cells $(10.0 \mu \mathrm{g}$ protein for anandamide and $3.0 \mu \mathrm{g}$ protein for $2-\mathrm{AG}$ ) was allowed to react with different concentrations of anandamide (closed circles) or 2-AG (open circles). The enzyme activities were analyzed by reverse-phase HPLC, and mean values \pm S.D. are shown $(n=3)$. 


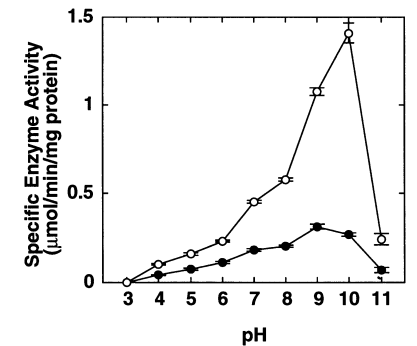

Fig. 3. pH-dependent hydrolysis of anandamide and 2-AG. The particulate fraction of the transfected COS-7 cells $(10.0 \mu \mathrm{g}$ protein for anandamide and $3.0 \mu \mathrm{g}$ protein for $2-\mathrm{AG}$ ) was allowed to react with $50 \mu \mathrm{M}$ anandamide (closed circles) or $50 \mu \mathrm{M}$ 2-AG (open circles) at different $\mathrm{pH}$. The buffers $(50 \mathrm{mM})$ used were: glycine$\mathrm{HCl}$ at $\mathrm{pH} 3.0$, citrate-sodium phosphate at $\mathrm{pH} 4.0,5.0,6.0$ and 7.0, Tris- $\mathrm{HCl}$ at $\mathrm{pH} 8.0$ and 9.0 , and $\mathrm{NaHCO}_{3}-\mathrm{NaOH}$ at $\mathrm{pH} 10.0$ and 11.0. The enzyme activities were analyzed by reverse-phase HPLC, and mean values \pm S.D. are shown $(n=3)$.

for 2-AG was about $6 \mu \mathrm{M}$ (Fig. 2B). Under the same assay conditions, the $K_{\mathrm{m}}$ for anandamide was also about $6 \mu \mathrm{M}$.

We also examined the reactivity of $2-\mathrm{AG}$ with anandamide amidohydrolase partially purified from the microsomes of porcine liver (the method of enzyme purification will be published elsewhere by Y. Kurahashi of our department). 2-AG hydrolysis occurred with a specific enzyme activity of 0.34 $\mu \mathrm{mol} / \mathrm{min} / \mathrm{mg}$ protein, which was 3.7 -fold higher than that with anandamide under the same conditions. Thus, the porcine enzyme also possesses a monoacylglycerol lipase activity although we cannot rule out the contamination of other enzymes hydrolyzing 2-AG.

Previously we demonstrated that anandamide amidohydrolase catalyzed the reverse reaction, namely, the condensation of arachidonic acid and ethanolamine forming anandamide at a rate comparable to that of the anandamide hydrolysis $[9,17]$. Therefore, we were interested in the synthesis of monoarachidonoylglycerol in the reverse reaction. However, when the recombinant enzyme was incubated with $200 \mu \mathrm{M}$ $\left[{ }^{14} \mathrm{C}\right]$ arachidonic acid in the presence of $2 \mathrm{M}$ glycerol, the specific synthase activity was as low as $2 \mathrm{nmol} / \mathrm{min} / \mathrm{mg}$ protein.

We also compared the $\mathrm{pH}$ dependence of the 2-AG hydrolysis with that of the anandamide hydrolysis (Fig. 3). Anandamide hydrolysis was active at alkaline $\mathrm{pH}$, and the optimum $\mathrm{pH}$ was 9.0, consistent with previous reports [9,22]. 2-AG hydrolysis was also active at alkaline $\mathrm{pH}$, but the highest activity was observed at $\mathrm{pH} 10.0$ rather than $\mathrm{pH} 9.0$.

PMSF [7] and MAFP [23,24], which were reported previously to inhibit anandamide amidohydrolase, also inhibited the 2-AG hydrolysis dose-dependently with $\mathrm{IC}_{50}$ values of $8 \mu \mathrm{M}$ and $5 \mathrm{nM}$, respectively. These $\mathrm{IC}_{50}$ values were similar to those for the anandamide hydrolysis, $7 \mu \mathrm{M}$ and $4 \mathrm{nM}$, under the same assay conditions (Fig. 4). Furthermore, in order to examine the competition between anandamide and 2-AG, we incubated $50 \mu \mathrm{M}\left[{ }^{14} \mathrm{C}\right] 2-\mathrm{AG}$ in the presence of various concentrations of non-radioactive anandamide (Fig. $5 \mathrm{~A})$. The result showed that the formation of $\left[{ }^{14} \mathrm{C}\right]$ arachidonic acid decreased with increasing concentrations of anandamide with an $\mathrm{IC}_{50}$ of about $50 \mu \mathrm{M}$. Similarly, the hydrolysis of 50 $\mu \mathrm{M}\left[{ }^{14} \mathrm{C}\right]$ anandamide was inhibited by increasing concentrations of non-radioactive 2-AG (Fig. 5B). These results suggest
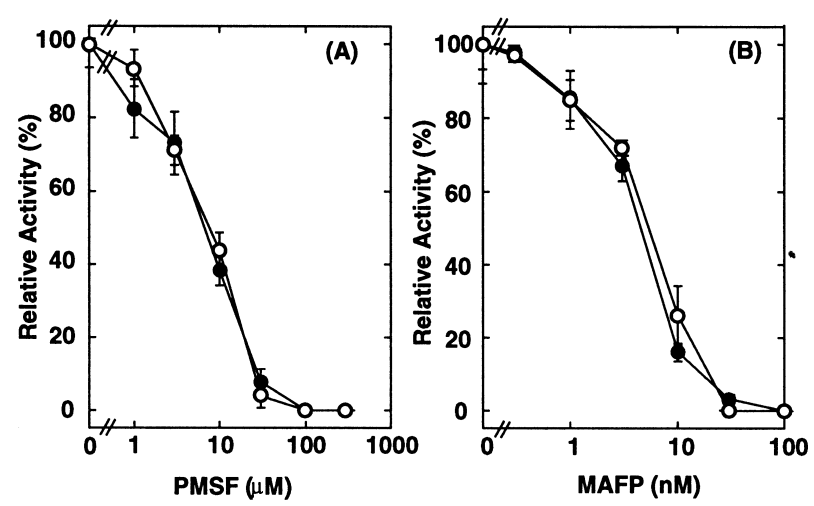

Fig. 4. Inhibition of the enzymatic hydrolysis of anandamide and 2AG by PMSF and MAFP. The particulate fraction of the transfected COS-7 cells $(10.0 \mu \mathrm{g}$ protein for anandamide and $3.0 \mu \mathrm{g}$ protein for 2-AG) was allowed to react with $50 \mu \mathrm{M}$ anandamide (closed circles) or $50 \mu \mathrm{M} 2-\mathrm{AG}$ (open circles) in the presence of different concentrations of PMSF (A) or MAFP (B). The enzyme was incubated with the inhibitors for $10 \mathrm{~min}$ at $24^{\circ} \mathrm{C}$ prior to the addition of the substrate. The enzyme activities were analyzed by reverse-phase HPLC, and mean values \pm S.D. are shown $(n=3)$. The activity in the absence of the inhibitors was expressed as $100 \%$; anandamide hydrolysis, $0.30 \mu \mathrm{mol} / \mathrm{min} / \mathrm{mg}$ protein; 2-AG hydrolysis, $1.13 \mu \mathrm{mol} / \mathrm{min} / \mathrm{mg}$ protein.

that anandamide and 2-AG are hydrolyzed by the same enzyme protein.

We also examined the reactivity of anandamide amidohydrolase with other monoacylglycerols and diacylglycerols. 1AG (specific activity of $1.22 \pm 0.11 \mu \mathrm{mol} / \mathrm{min} / \mathrm{mg}$ protein, $n=3)$ was as active as $2-\mathrm{AG}(1.13 \pm 0.12)$. 1-Oleoylglycerol was less active $(0.63 \pm 0.12)$. In contrast to monoacylglycerols, diacylglycerols like 1-stearoyl-2-arachidonylglycerol, 1,2-dioleoylglycerol and 1,3-dioleoylglycerol were inactive.

\section{Discussion}

Anandamide, an endogenous cannabinoid receptor ligand, has been shown to be hydrolyzed by an enzyme referred to as
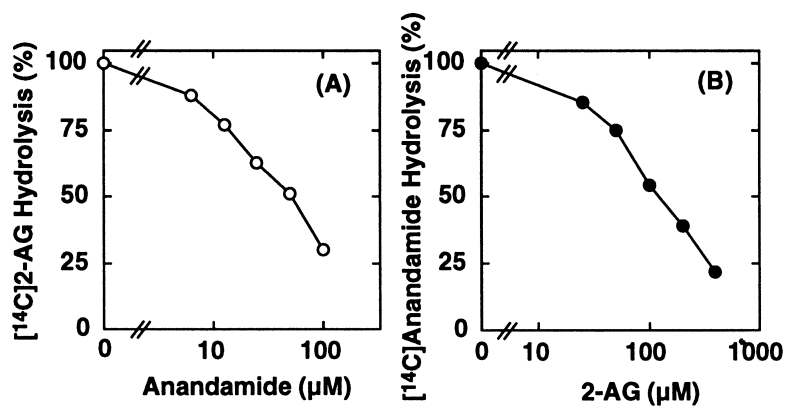

Fig. 5. Competition between 2-AG and anandamide as substrates for anandamide amidohydrolase. A: The particulate fraction of the transfected COS-7 cells $(2.0 \mu \mathrm{g}$ protein) was allowed to react with $50 \mu \mathrm{M}\left[{ }^{14} \mathrm{C}\right] 2-\mathrm{AG}$ in the presence of different concentrations of anandamide. The activity in the absence of anandamide $(0.64 \mu \mathrm{mol} /$ $\mathrm{min} / \mathrm{mg}$ protein) was expressed as $100 \%$. B: The particulate fraction of the transfected COS-7 cells $(6.0 \mu \mathrm{g}$ protein) was allowed to react with $50 \mu \mathrm{M}\left[{ }^{14} \mathrm{C}\right]$ anandamide in the presence of different concentrations of $2-\mathrm{AG}$. The activity in the absence of $2-\mathrm{AG}(0.20 \mu \mathrm{mol} / \mathrm{min} /$ mg protein) was expressed as $100 \%$. Anandamide and $2-A G$ were simultaneously added to the reaction mixture. The enzyme activities were analyzed by TLC as described in Section 2, and mean values are shown $(n=2)$. 
anandamide amidohydrolase [7-17]. 2-AG, another recently discovered ligand, was thought to lose its biological activities when it is hydrolyzed to arachidonic acid and glycerol by monoacylglycerol lipase [6]. Previously, Bisogno and others considered the possibility that 2-AG was hydrolyzed by anandamide amidohydrolase of $\mathrm{N}_{18} \mathrm{TG}_{2}$ cells. However, on the basis of their experimental findings the authors stated that "the possibility of the existence of a specific lipase for 2-AG hydrolysis, responsible for the physiological inactivation of this putative mediator, should be investigated in future studies" [25]. Recently, we showed that the hydrolysis of $\left[{ }^{14} \mathrm{C}\right]$ anandamide by rat liver microsomes was dose-dependently inhibited by 2-AG [15]. In the present study we demonstrated that 2-AG was hydrolyzed as well as anandamide by the particulate fraction of COS-7 cells overexpressing rat anandamide amidohydrolase, whereas the control cells transfected with the insert-free vector did not hydrolyze 2-AG. 2AG was much more active than anandamide when compared at saturating concentrations. The $K_{\mathrm{m}}$ value for 2 -AG $(6 \mu \mathrm{M})$ was as low as that for anandamide $(6 \mu \mathrm{M})$. The $2-\mathrm{AG}$ hydrolysis was similar to the anandamide hydrolysis in terms of $\mathrm{pH}$ dependence and inhibitory effects of PMSF and MAFP. Furthermore, 2-AG inhibited competitively the anandamide hydrolysis catalyzed by the enzyme. These results demonstrate that a recombinant anandamide amidohydrolase has a potent monoacylglycerol lipase activity hydrolyzing 2-AG. The 2-AG hydrolase activity was also observed with anandamide amidohydrolase preparations of $\mathrm{N}_{18} \mathrm{TG}_{2}$ and RBL-2H3 cells (personal communication from $\mathrm{V}$. Di Marzo).

Recently 1-AG was shown to be as active as $2-\mathrm{AG}$ in terms of cannabimimetic effects like the decrease in cAMP accumulation and the prevention of induction of long-term potentiation [26]. Since 2-AG is easily transformed to $1-A G$, a part of 2-AG may act as a cannabinoid receptor ligand after its conversion to $1-A G$. Our results show that $1-A G$ is as good a substrate as 2-AG for anandamide amidohydrolase. Therefore, the enzyme may hydrolyze $2-\mathrm{AG}$ in vivo either as such or after its conversion to $1-\mathrm{AG}$.

The nature of various lipases responsible for the hydrolysis of monoacylglycerol is not well known [27]. Earlier a monoacylglycerol lipase, distinguished from a hormone-sensitive lipase, was purified from adipose tissues of rat [28] and chicken [29]. Monoacylglycerol lipase of blood platelets and neutrophils was shown to be involved in the sequential breakdown of 1,2-diacylglycerol, resulting in the release of arachidonic acid from the $s n-2$ position [30-32]. The enzyme of human platelet microsomes showed a $K_{\mathrm{m}}$ value of $12.3 \mu \mathrm{M}$ for 2-AG, and its optimal pH was 7.0 [33]. Recently, a monoacylglycerol lipase was purified from human erythrocytes, and its molecular weight was estimated to be $68 \mathrm{kDa}$ [27]. Alternatively, several non-specific carboxylesterases of the liver microsomes were shown to have a monoacylglycerol lipase-like activity [34,35]. These monoacylglycerol lipases so far reported are distinguishable from anandamide amidohydrolase (63 kDa [16]) on the basis of their catalytic properties and molecular weights. Thus, 2-AG may be hydrolyzed by a variety of enzymes including anandamide amidohydrolase in vivo. This is in sharp contrast to the fact that only anandamide amidohydrolase is so far known as an enzyme capable of hydrolyzing anandamide.

Cannabinoid receptor was colocalized with the anandamide amidohydrolase activity in various regions of rat brain $[8,10]$.
Thus, anandamide amidohydrolase may participate in the inactivation of both anandamide and $2-\mathrm{AG}$ in or near the cells expressing cannabinoid receptors. In terms of the physiological role of the enzyme it should be noted that the amidohydrolase and carboxylesterase activities of the same enzyme are responsible for the hydrolysis and inactivation of two different types of ligand for cannabinoid receptors.

Acknowledgements: This work was supported by grants-in-aid for scientific research from the Ministry of Education, Science, Sports and Culture of Japan, Human Frontier Science Program, the Japanese Foundation of Metabolism and Disease, Ono Medical Research Foundation, the Japan Foundation for Applied Enzymology, Ono Pharmaceutical Company, Kissei Pharmaceutical Company, Sankyo Company, Japan Tobacco Company, and Takeda Pharmaceutical Industry.

\section{References}

[1] Onaivi, E.S., Chakrabarti, A. and Chaudhuri, G. (1996) Prog. Neurobiol. 48, 275-305.

[2] Matsuda, L.A. (1997) Crit. Rev. Neurobiol. 11, 143-166.

[3] Pertwee, R.G. (1997) Pharmacol. Ther. 74, 129-180.

[4] Devane, W.A., Hanus, L., Breuer, A., Pertwee, R.G., Stevenson, L.A., Griffin, G., Gibson, D., Mandelbaum, A., Etinger, A. and Mechoulam, R. (1992) Science 258, 1946-1949.

[5] Mechoulam, R., Ben-Shabat, S., Hanus, L., Ligumsky, M., Kaminski, N.E., Schatz, A.R., Gopher, A., Almog, S., Martin, B.R., Compton, D.R., Pertwee, R.G., Griffin, G., Bayewitch, M., Barg, J. and Vogel, Z. (1995) Biochem. Pharmacol. 50, 83-90.

[6] Sugiura, T., Kondo, S., Sukagawa, A., Nakane, S., Shinoda, A., Itoh, K., Yamashita, A. and Waku, K. (1995) Biochem. Biophys. Res. Commun. 215, 89-97.

[7] Deutsch, D.G. and Chin, S.A. (1993) Biochem. Pharmacol. 46, 791-796.

[8] Desarnaud, F., Cadas, H. and Piomelli, D. (1995) J. Biol. Chem. 270, 6030-6035.

[9] Ueda, N., Kurahashi, Y., Yamamoto, S. and Tokunaga, T. (1995) J. Biol. Chem. 270, 23823-23827.

[10] Hillard, C.J., Wilkinson, D.M., Edgemond, W.S. and Campbell, W.B. (1995) Biochim. Biophys. Acta 1257, 249-256.

[11] Paria, B.C., Deutsch, D.G. and Dey, S.K. (1996) Mol. Reprod. Dev. 45, 183-192.

[12] Watanabe, K., Kayano, Y., Matsunaga, T., Yamamoto, I. and Yoshimura, H. (1996) Biol. Pharm. Bull. 19, 1109-1111.

[13] Bisogno, T., Maurelli, S., Melck, D., De Petrocellis, L. and Di Marzo, V. (1997) J. Biol. Chem. 272, 3315-3323.

[14] Matsuda, S., Kanemitsu, N., Nakamura, A., Mimura, Y., Ueda, N., Kurahashi, Y. and Yamamoto, S. (1997) Exp. Eye Res. 64, $707-711$.

[15] Katayama, K., Ueda, N., Kurahashi, Y., Suzuki, H., Yamamoto, S. and Kato, I. (1997) Biochim. Biophys. Acta 1347, 212-218.

[16] Cravatt, B.F., Giang, D.K., Mayfield, S.P., Boger, D.L., Lerner, R.A. and Gilula, N.B. (1996) Nature 384, 83-87.

[17] Kurahashi, Y., Ueda, N., Suzuki, H., Suzuki, M. and Yamamoto, S. (1997) Biochem. Biophys. Res. Commun. 237, 512515.

[18] Ueda, N., Yamamoto, K., Yamamoto, S., Tokunaga, T., Shirakawa, E., Shinkai, H., Ogawa, M., Sato, T., Kudo, I., Inoue, K., Takizawa, H., Nagano, T., Hirobe, M., Matsuki, N. and Saito, H. (1995) Biochim. Biophys. Acta 1254, 127-134.

[19] Sémériva, M., Benzonana, G. and Desnuelle, P. (1969) Biochim. Biophys. Acta 191, 598-610.

[20] Bradford, M.M. (1976) Anal. Biochem. 72, 248-254.

[21] Gunstone, F.D. (1979) in: Comprehensive Organic Chemistry (Barton, D.H.R. and Ollis, W.D., Eds.), Vol. 5, pp. 633-664, Pergamon, Oxford.

[22] Maurelli, S., Bisogno, T., De Petrocellis, L., Di Luccia, A., Marino, G. and Di Marzo, V. (1995) FEBS Lett. 377, 82-86.

[23] Deutsch, D.G., Omeir, R., Arreaza, G., Salehani, D., Prestwich, G.D., Huang, Z. and Howlett, A. (1997) Biochem. Pharmacol. $53,255-260$.

[24] De Petrocellis, L., Melck, D., Ueda, N., Maurelli, S., Kurahashi, 
Y., Yamamoto, S., Marino, G. and Di Marzo, V. (1997) Biochem. Biophys. Res. Commun. 231, 82-88.

[25] Bisogno, T., Sepe, N., Melck, D., Maurelli, S., De Petrocellis, L. and Di Marzo, V. (1997) Biochem. J. 322, 671-677.

[26] Stella, N., Schweitzer, P. and Piomelli, D. (1997) Nature 388, 773-778.

[27] Somma-Delpéro, C., Valette, A., Lepetit-Thévenin, J., Nobili, O., Boyer, J. and Vérine, A. (1995) Biochem. J. 312, 519-525.

[28] Tornqvist, H. and Belfrage, P. (1976) J. Biol. Chem. 251, 813819.

[29] Berglund, L., Khoo, J.C., Jensen, D. and Steinberg, D. (1980) J. Biol. Chem. 255, 5420-5428.
[30] Prescott, S.M. and Majerus, P.W. (1983) J. Biol. Chem. 258, 764 769.

[31] Chau, L.-Y. and Tai, H.-H. (1983) Biochem. Biophys. Res. Commun. 113, 241-247.

[32] Balsinde, J., Diez, E. and Mollinedo, F. (1991) J. Biol. Chem. 266, 15638-15643.

[33] Chau, L.-Y. and Tai, H.-H. (1988) Biochim. Biophys. Acta 963, 436-444.

[34] Mentlein, R., Suttorp, M. and Heymann, E. (1984) Arch. Biochem. Biophys. 228, 230-246.

[35] Mentlein, R., Berge, R.K. and Heymann, E. (1985) Biochem. J. 232, 479-483. 